УДК 332.338

$10.17213 / 2075-2067-2019-4-123-127$

\title{
АНАЛИЗ ПЛАНИРОВОЧНОЙ И ФУНКЦИОНАЛЬНО-ПРОИЗВОДСТВЕННОЙ ОРГАНИЗАЦИИ ТЕРРИТОРИИ ГОРОДА С ЦЕЛЬЮ ЕЕ РАЦИОНАЛЬНОГО ИСПОЛЬЗОВАНИЯ
}

\author{
(C) 2019 г. Н. Г. Овчинникова *, Н. В. Алиева ** \\ *Донской государственный технический университет, \\ 2. Ростов-на-Дону \\ **Новочеркасский инженерно-мелиоративный институт \\ им. А. К. Кортунова ФГБОУ ВО «ДГАУ»
}

Градостроительное зонирование территорий и его виды осуществляются на основе анализа планировочной и функционально-производственной организации территории города. В статье рассмотрены основные виды зонирования территории с последовательностью выполнения всех видов работ, необходимых для выявления проблем в городе. Для дальнейтего функционального использования территории города согласно нормам и правилам планировки и застройки городов необходим ее тщательный анализ, причем с учетом каждого земельного участка, для чего необходима качественная информационная база.

Ключевые слова: территория; зонирование; земельный участок; красная линия организации территории; градостроительное зонирование; территориальная зона.

Town-planning zoning of territories and its types is carried out on the basis of the analysis of planning and functional and industrial organization of the territory of the city. The article describes the main types of zoning of the territory with the sequence of all types of work necessary to identify problems in the city. For further functional use of the territory of the city, according to the rules and regulations of planning and development of cities, it is necessary to carefully analyze it, and taking into account each land plot, which requires a quality information base.

Key words: area; zoning; land; the red line of the organization of the territory; zoning; territorial area.

Актуальность градостроительного зонирования подразумевает то, что анализ планировочной и функционально-производственной организации территории города должен основываться на регулярно актуализуемой информации о состоянии и рациональном использовании территории [1].

Градостроительное зонирование установление обязательных требований к функциональному использованию, застройке, ландшафтной организации планировочных районов и кварталов во всех районах города.
Карта градостроительного зонирования устанавливает границы территориальных зон, которые должны отвечать требованию принадлежности каждого земельного участка только к одной территориальной зоне.

Градостроительное зонирование на карте выполняется с помощью линий градостроительного регулирования: красные линии линии, которые обозначают существующие, планируемые (измененные, вновь сформированные) границы территорий общего пользования, границы земельных участков, на которых находятся линии электропередач, линии 
связи (в том числе линейно-кабельные сооружения), трубопроводы, дороги, железнодорожные линии и другие подобные сооружения (далее - линейные объекты) [2].

Красные линии должны иметь определенный юридический статус, соответствующий юридическому статусу генерального плана как закона для развития города.

Если красная линия (линия ограничения застройки, линии строительных кварталов, полосы отвода железных дорог и т.д.) проходит через земельный участок, то земельный участок распадается на два земельных участка с различным юридическим статусом, режимом использования и кадастровыми номерами.

Рассмотрим подробнее некоторые из видов зонирования.

Функциональное зонирование - наиболее полная форма учета разнообразных требований к рациональному землепользованию, включающая комплекс нормативных параметров (целевое назначение участка, его предельные размеры, коэффициент застройки и т.д.). Это установление и выделение на картографическом материале границ территории по назначению [3].

Функциональное зонирование означает дифференциацию территории города по характеру и типу ее использования. В основе функционального зонирования - стремление создать наиболее эффективные условия реализации основных форм жизнедеятельности городского населения — труда, быта и отдыха - предъявляющих специфические требования к организации городского пространства.

Зонирование территории [4] заключается в выделении экономических зон, относительно однородных по социально-градостроительным характеристикам. Основные требования к выделению экономических зон - это совмещение границ зон с границами кадастровых учетных единиц и сплошное покрытие территории города без пропусков и перекрытий. Методической основой зонирования служит анализ планировочной и функционально-производственной организации территории города [5].

Зонирование включает следующие стадии работ.

1. Подготовительный этап. Подготовка и описание. Постановление местного органа власти о проведении зонирования. На основе этого постановления: сбор и анализ, изучение, идентификация и анализ действующих законодательных, инструктивно-нормативных, проектно-изыскательских, плановокартографических материалов, содержащих информацию о территории города [6]. На основании собранных материалов устанавливается необходимость проведения полевых обследований и геодезических работ.

2. Изготовление плана зонирования территории.

3. Составление плана обременений карта функционального зонирования с нанесением на ней границ земельного участка.

4. Согласование и утверждение материалов.

Согласно нормам и правилам планировки и застройки городов с учетом преимущественного функционального использования территория города [7] укрупненно подразделяется на селитебную, производственную и ландшафтно-рекреационную.

Селитебная территория предназначается для размещения жилищного фонда, общественных зданий и сооружений. Здесь располагаются научно-исследовательские, проектные институты, отдельные коммунальные, промышленные и другие объекты, не требующие устройства санитарно-защитных зон. В пределах селитебной территории размещаются пути внутригородских сообщений, площади, парки, сады, бульвары и другие места общего пользования.

Производственная территория предназначена для размещения промышленных предприятий и комплексов научных учреждений со связанными с ними опытными производствами. Во взаимосвязи с производственными территориями формируются участки коммунально-складских объектов, сооружений внешнего транспорта (пути внегородских сообщений, сортировочные, технические станции, контейнерные площадки транспорта и т.д.).

Ландшафтно-рекреационная территория включает городские леса, лесопарки, лесозащитные зоны, водоемы, земли сельскохозяйственного использования. Совместно с парками, садами, скверами и бульварами, размещаемыми на селитебной территории, они формируют непрерывную систему открытых пространств города и его окружения [8]. 
Функциональное зонирование обеспечивает благоприятные условия для труда и отдыха населения, учитывая специфические характеристики каждой из зон.

В соответствии с Градостроительным кодексом в городских и сельских поселениях проводится территориальное зонирование. Оно основано на выделении зон поселения, объединенных функциональным использованием, параметрами и ограничениями на их застройку [9].

Состав территориальных зон в поселениях может различаться в зависимости от местных условий, нормативных правовых и нормативно-технических документов субъектов Российской Федерации и органов местного самоуправления в области рационального использования территории. Примерный перечень территориальных зон городских и сельских поселений установлен в Градостроительном кодексе и включает в себя: жилые зоны, общественно-деловые зоны, производственные зоны, зоны инженерной и транспортной инфраструктур, рекреационные зоны, зоны сельскохозяйственного использования, зоны специального назначения, зоны военных объектов, иные зоны режимных территорий.

Выделение отдельных зон при застройке жилой территории населенного места в соответствии с типами и этажностью жилых домов и строительными материалами, из которых они возведены, называют строительным зонированием. В этом случае эффективно используют территорию населенного места, а затраты на благоустройство и инженерное оборудование будут оптимальны [10].

При разработке схемы строительного зонирования устанавливается этажность жилых зданий. Характер хозяйственного использования территории кварталов определяется плотностью их заселения и в известной мере обусловливается той или иной степенью санитарно-технического оборудования и благоустройства каждой зоны.

При размещении жилой застройки на территории сельского населенного места выделяют три основные строительные зоны: зону секционной застройки в 2-5 этажей, зону застройки блокированными домами с квартирами в двух уровнях, зону застройки индивидуальными домами.
Граница зон устанавливается либо по улицам, либо по кварталам. В первом случае застройка улиц будет иметь различную этажность на каждой стороне, во втором одинаковую.

На установление строительных зон, определение их количества и размеров влияют в основном следующие факторы: численность населения, характер строительного материала, геологические условия, экономические возможности, архитектурно-планировочные требования, очередность строительства.

При строительном зонировании желательно придерживаться принципа постепенного снижения высоты застройки от центра к периферии. В целях архитектурной выразительности, выявления общественного центра населенного пункта здания повышенной этажности желательно намечать в первую очередь на площади и в центральных частях населенного места.

Одноэтажную, усадебного типа застройку желательно размещать на окраине населенного пункта, а также в местах с пересеченным или крутым рельефом. Застройку любой строительной зоны с любым типом жилья экономически целесообразно располагать как можно более компактно.

Строительных зон в населенном месте может быть несколько, но практически их бывает не более двух-трех. Чтобы избежать монотонности в застройке населенного места, можно допускать в отдельных местах размещение зданий общественного назначения. Их повышенная этажность и характер архитектуры будут вносить желательное разнообразие в объемно-пространственную композицию жилой застройки.

Ландшафтное зонирование устанавливает в каждой планировочной единице предельные доли участков естественных открытых поверхностей (растительность, водные поверхности), искусственных покрытий (замощенные пространства) и территории, занятой зданиями и сооружениями.

Таким образом, для рационального использования территории необходимо провести градостроительный анализ, на основе чего принять проектное решение с целью обеспечения полноценного правового режима для каждого земельного участка, что невозможно без наличия качественной информационной базы. 


\section{Литература}

1. Овчинникова Н.Г., Шумкова Е.С. Учетно-регистрационный процесс в системе управления земельными ресурсами // Экономика и экология территориальных образований. - 2016. - №2. - С. 125-129.

2. Овчинникова Н.Г., Русских А.В. Некоторые особенности разрешенного использования земельного участка с учетом градостроительного регулирования // Экономика и экология территориальных образований. 2017. 一 №1. - С. 31-36.

3. Овчинникова Н.Г., Асанова Н.В. Рациональное землепользование как фактор развития территориально-хозяйственной системы населенных пунктов // В сборнике: Российская экономическая модель-5: настоящее и будущее аграрного, индустриального и постиндустриального сектора. Сборник статей по материалам Международной научно-практической конференции, посвященной 55-летию экономического факультета ГубГАУ. — 2015. C. 425-430.

4. Овчинникова Н.Г., Бружукова О.В. Экономико-правовое содержание градостроительной деятельности Ростовской области: исторический аспект // Вестник Московского государственного университета культуры и искусств. - 2014. - №4 (60). — С. 201205.

5. Овчинникова Н.Г. Использование и охрана земельных ресурсов в системе рационального землепользования // Землеустройс- тво, кадастр и мониторинг земель. - 2011. №6 (78). - С. 83-91.

6. Овчинникова Н.Г. Организационнотерриториальные аспекты использования земельных ресурсов // Инженерный вестник Дона. - 2011. — №3 (17). - С. 236-240.

7. Овчинникова Н.Г., Алиева Н.В., Шипулин Я.В. Совершенствование социо-эколого-экономического механизма устойчивого развития сельских территорий в аграрном природопользовании // Инженерный вестник Дона. - 2013. - Т. 27. - №4. - С. 187.

8. Русских А.В., Овчинникова Н.Г. Значимость документов территориального планирования муниципального образования для ведения ЕГРН // Научные труды Кубанского государственного технологического университета. - 2017. - Т. 9. — №4. - С. 285-289.

9. Овчинникова Н.Г., Гаранова М.В., Бурдова Д. В. Устойчивое развитие территории посредством градостроительной деятельности // Вестник Южно-Росийского государственного технического университета (Новочеркасского политехнического института). Серия: Социально-экономические науки. 2018. - №1. - С. 57-60.

10. Русских А.В., Овчинникова Н.Г. Устойчивое развитие муниципальных образований посредством их зонирования // В сборнике: Организационно-экономические проблемы регионального развития в современных условиях. Материалы научно-практической конференции. - 2017. - С. 276-277. 


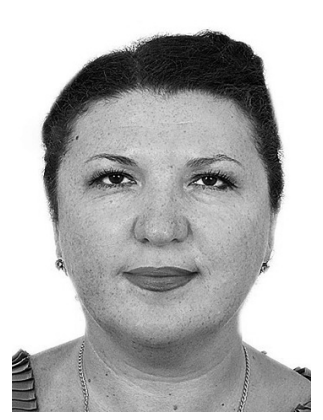

Овчинникова Наталья Геннадьевна - кандидат экономических наук, доцент кафедры экономики природопользования и кадастра Донского государственного технического университета.

Ovchinnikova Natalya Gennadyevna - Candidate of Economic Sciences, Associate Professor of Department of environmental Economics and cadastre of Don State Technical University.

344022, г. Ростов-на-Дону, пл. Гагарина, 1

1 Gagarin sq., 344022, Rostov-on-Don, Russia

Тел.: +7 (951) 493-48-92; e-mail: natali281280@yandex.ru

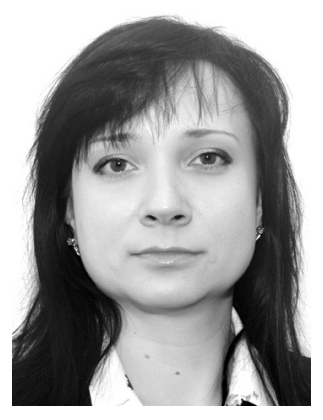

Алиева Наталья Владимировна - кандидат экономических наук, доцент кафедры землепользования и землеустройства Новочеркасского инженерно-мелиоративного института им. А.К. Кортунова ФГБОУ ВО «Донской государственный аграрный университет».

Alieva Natalya Vladimirovna - Candidate of Economic Sciences, Associate Professor of land use and land management Department of Novocherkassk Engineering Meliorative Institute named after A. K. Kortunov FSBEI HE «Donskoy State Agrarian University».

346400 , г. Новочеркасск, ул. Пушкинская, 111

111 Pushkinskaya st., 346400, Novocherkassk, Russia

Тел.: +7 (951) 493-48-92; e-mail: natali281280@yandex.ru 